\title{
Turnover of Acylglucose, Acyltrehalose and Free Trehalose during Growth of Mycobacterium smegmatis on Glucose
}

\author{
By F. G. WINDER, J. J. TIGHE AND P. J. BRENNAN* \\ Department of Biochemistry, Trinity College, Dublin 2 \\ Republic of Ireland
}

(Received 9 March 1972 ; revised 28 July 1972)

\begin{abstract}
SUMMARY
When Mycobacterium smegmatis was in an approximately balanced state of growth on glucose as the sole carbon source, free trehalose turned over at about 3 times the rate of its net formation, while the sugars of acyltrehalose and acylglucose turned over at about 13 and 8 times the rate of their net formation, respectively. Total lipid turned over substantially more slowly than this, while turnover of polysaccharide and of cell residue was slight or non-existent. However, in spite of their high turnover, the acylated sugars did not represent a major pathway of glucose metabolism, because of their low content in the bacteria.
\end{abstract}

\section{INTRODUCTION}

In 1956 'cord factor', a toxic lipid which occurs widely in mycobacteria, was shown to be 6,6'-dimycolyl- $\alpha$-D-trehalose (Noll, Bloch, Asselineau \& Lederer, I956). This represented the first discovery of a simple acylated sugar in a micro-organism. More recently, acylated forms of glucose have been reported from Mycoplasma sp. (Smith \& Mayberry, 1968), Streptococcus faecalis (Welsh, Shaw \& Baddiley, 1968), corynebacteria and mycobacteria (Brennan \& Lehane, 1969; Brennan, Lehane \& Thomas, 1970), Escherichia coli, Saccharomyces cerevisiae and Agaricus bisporus (Brennan, Flynn \& Griffin, 1970). Acylated forms of other sugars and sugar alcohols have also been found in some of these organisms. Thus, acylated sugars are widely distributed among prokaryotes and occur in eukaryotes.

However, little or nothing is known about the biosynthesis, catabolism, or functions of the acylated sugars (Shaw, 1970). The work described in this paper was done in order to learn something about the metabolism of the acylated sugars and to remove some of the possible hypotheses about their biological roles.

\section{METHODS}

Organism. Mycobacterium smegmatis, strain I.T.P. (ATCC21732), was a gift from Dr J. F. Petit, Institut de Biochimie, Université de Paris.

Medium. The medium contained (per 1): $\left(\mathrm{NH}_{4}\right)_{2} \mathrm{SO}_{4}, 8 \mathrm{~g} ; \mathrm{KH}_{2} \mathrm{PO}_{4}, 5 \mathrm{~g} ; \mathrm{MgSO}_{4} \cdot 7 \mathrm{H}_{2} \mathrm{O}$, $0.5 \mathrm{~g} ; \mathrm{Fe}^{2+}$ (as the sulphate), $2 \mathrm{mg}$ and $\mathrm{Zn}^{2+}$ (as the sulphate), $0.4 \mathrm{mg}$. The $\mathrm{pH}$ was adjusted to 6.8 with IO $\mathrm{M}-\mathrm{NaOH}$. Medium was in $500 \mathrm{ml}$ lots held in I 1 conical flasks and autoclaved at $10 \mathrm{lb} / \mathrm{in}^{2}$ for $20 \mathrm{~min}$. Glucose was autoclaved separately as a $20 \%$ solution and added to give a concentration of $\mathrm{I} \%$.

Growth and exposure to $\left[{ }^{44} \mathrm{C}\right]$ glucose. Mycobacterium smegmatis was inoculated into the

* Present address: Department of Biochemistry, University College, Dublin. 
above medium and the cultures were incubated at $37^{\circ} \mathrm{C}$ on a rotary shaker. After 3 days of growth II $\mu \mathrm{Ci}$ of $\mathrm{D}-\left[\mathrm{U}-{ }^{14} \mathrm{C}\right] \mathrm{glucose}(360 \mathrm{Ci} / \mathrm{mol})$ was added to each of 15 to 20 flasks. After various periods of time up to $8 \mathrm{~h}$ the bacteria from batches of five flasks were harvested by filtration through Whatman no. I paper on a Büchner funnel, washed with about $500 \mathrm{ml}$ of water and sucked dry. Samples of the medium obtained after each harvesting were retained.

Extraction of the bacteria. The pooled bacteria from five flasks (about $10 \mathrm{~g}$ wet $\mathrm{wt}$ ) were extracted with $\mathrm{I} 50 \mathrm{ml}$ of chloroform + methanol ( $\mathrm{I}: \mathrm{I}, \mathrm{v} / \mathrm{v}$ ) with shaking at room temperature for $8 \mathrm{~h}$. A further extraction with $\mathrm{I} 50 \mathrm{ml}$ of chloroform + methanol $(2: \mathrm{I}, \mathrm{v} / \mathrm{v})$ was carried out under the same conditions, followed by extraction twice with $80 \mathrm{ml}$ of ethanol + diethyl ether $(3: \mathrm{I}, \mathrm{v} / \mathrm{v})$ at $50^{\circ} \mathrm{C}$ for $\mathrm{I} \mathrm{h}$ and once with $80 \mathrm{ml}$ of ethanol at $50^{\circ} \mathrm{C}$ for $\mathrm{I} \mathrm{h}$. The combined extracts were evaporated to dryness in a rotary evaporator to give the 'crude lipid' which was dried in vacuo over $\mathrm{P}_{2} \mathrm{O}_{5}$, weighed and treated as described below. The delipidated bacterial residue was treated as described below.

Fractionation of the crude lipid. The crude lipid, which also contained water-soluble components of small molecular weight from the bacteria, was extracted first with io $\mathrm{ml}$ of Folch II solvent (chloroform + methanol + water, $86: 14: \mathrm{I}$, by vol.), and then by $6 \mathrm{ml}$ of Folch I solvent (chloroform + methanol + water, 3:48:47, by vol.) (Folch, Lees \& SloaneStanley, 1957). The extractions were repeated with the same volumes of the two Folch solvents, followed by $10 \mathrm{ml}$ of Folch II. The extracts were combined and the phases were separated by centrifugation to give the Folch I fraction (the upper, aqueous layer) and the Folch II fraction.

Examination of Folch I fraction. This fraction contained the free monosaccharides and oligo-saccharides from the bacteria, together with other water-soluble components. Samples were taken for determining radioactivity and total carbohydrate (see below). Most of the remainder was chromatographed, together with glucose and trehalose standards, as a band on Whatman no. I paper using ethyl acetate + acetic acid + formic acid + water $(18: 3: 1: 4$, by vol.), as solvent in a descending direction for $18 \mathrm{~h}$. The paper had been washed by running the same solvent down it for several days. The positions of the standards were visualized using the $\mathrm{AgNO}_{3}-\mathrm{NaOH}$ dip reagent (Anet \& Reynolds, 1954). The areas corresponding to glucose and trehalose were cut from the paper and the sugars were eluted with water. Samples of the eluates were taken for counting and determination of total carbohydrate. The resulting data gave the specific activity of trehalose, but the amount of glucose present was found to be too small for measurement.

Examination of Folch II fraction. This fraction, which contained the unbound lipid from the bacteria, was evaporated and the residue dried in vacuo over $\mathrm{P}_{2} \mathrm{O}_{5}$ and weighed. A sample was taken for counting, to obtain the overall specific activity of the lipid. The remainder was deacylated by the method of Ballou, Vilkas \& Lederer (I963) and the water-soluble material was chromatographed as described above to isolate glucose and trehalose derived from their acylated forms. Samples of the solution of glucose so obtained were counted and assayed for total carbohydrate to give its specific activity. Because the trehalose so obtained was contaminated with a non-carbohydrate, possibly inositol, it was hydrolysed with $2 \mathrm{M}-\mathrm{HCl}$ at $100^{\circ} \mathrm{C}$ for $3 \mathrm{~h}$. The hydrolysate was evaporated to dryness in a rotary evaporator. Residual $\mathrm{HCl}$ was removed by storage over $\mathrm{KOH}$ in a desiccator for $36 \mathrm{~h}$. The residue was dissolved, treated with mixed-bed resin (equal parts of Dowex AG $50 \mathrm{~W}-\mathrm{x} 8$, $\mathrm{H}^{+}$form, and Amberlite IR-45, $\mathrm{OH}^{-}$form), and was chromatographed in the above solvent system. The area corresponding to glucose was cut out and counts and total carbohydrate were determined in the eluate from this area. 
Examination of de-lipidated residue. This residue was dried in vacuo over $\mathrm{P}_{2} \mathrm{O}_{5}$ and weighed. A sample of residue was ground finely, weighed, suspended in toluene-based scintillation fluid containing $4 \% \mathrm{Cab}-\mathrm{O}-\mathrm{Sil}$ and counted. The remainder was hydrolysed with $2 \mathrm{M}-\mathrm{HCl}$ at $100^{\circ}$ for $3 \mathrm{~h}$. The hydrolysate was filtered, the filtrate was evaporated to dryness, residual $\mathrm{HCl}$ was removed, the residue was dissolved, treated with mixed-bed resin and a sample was chromatographed, all as described above. The area corresponding to glucose was eluted with water and the eluate was chromatographed on washed Whatman no. I paper in ethyl acetate + pyridine + water ( $10: 4: 3$, by vol.), in a descending direction, for $20 \mathrm{~h}$. The second chromatography step was necessary to separate glucose from galactose. The glucose area was eluted with water and samples of the eluate were counted and assayed for total carbohydrate, to obtain the specific activity of glucose derived from the hydrolysis of polysaccharide.

Examination of the medium. Samples of the medium were taken for counting and assay of carbohydrate. This gave the specific activity of the glucose in the medium, assuming that no appreciable amounts of other carbohydrates had been released during the growth of the bacteria. The validity of this assumption was checked on a number of occasions by determining the specific activity of the glucose after its isolation from the medium and subsequent chromatography in the ethyl acetate + acetic acid + formic acid + water system. This gave the same results.

Measurement of the doubling time of the bacteria. This was done by measurement of the dry wt of the bacteria recovered from five flasks harvested at the beginning and end of a I $2 \mathrm{~h}$ period equally spaced before and after the labelling period.

Assay of carbohydrate. The phenol method of Dubois, Gilles, Hamilton, Rebers \& Smith (1956) was used.

Scintillation counting of ${ }^{14} C$. Samples of lipid were counted in toluene containing $5 \mathrm{~g}$ of PPO (2,5-diphenyloxazole) and $0.3 \mathrm{~g}$ of POPOP (I,4-bis-(5-phenyloxazol-2-yl) benzene) per 1. Aqueous samples were counted in Bray's fluid (Bray, 1960). A Packard liquid scintillation counter, model 3380 , was used. The results were converted to d.p.m. by the external standard channels ratio method employing standard curves obtained with the two scintillation fluids.

\section{RESULTS}

Comparison of incorporation of ${ }^{14} \mathrm{C}$ into some fractions

A number of experiments were carried out in which the incorporation of ${ }^{14} \mathrm{C}$, from a medium which contained $\left[{ }^{14} \mathrm{C}\right]$ glucose as the sole carbon source, into some bacterial components was followed over total experimental periods varying from 2 to $8 \mathrm{~h}$. There was some variation from experiment to experiment in the growth rates of the bacteria, with consequent variations in the rates of incorporation of radioactivity into the various fractions, but the relative rates of incorporation into the fractions were always consistent. The results of a typical experiment are shown in Fig. I.

${ }^{14} \mathrm{C}$ was incorporated slowly, and approximately linearly over the experimental periods involved, into the de-lipidated cell residue (not shown in Fig. I), and only slightly more rapidly into the glucose of the polysaccharides contained in this residue. It was incorporated substantially more rapidly into the free trehalose of the soluble pool (Folch I fraction). An overall 'specific activity' was also calculated for the Folch I fraction by dividing the total d.p.m. in that fraction by the amount of carbohydrate. This, of course, represents an overestimate of the true average specific activity for the fraction, since components other than carbohydrate contributed to the radioactivity. However, since the bulk of material in the 


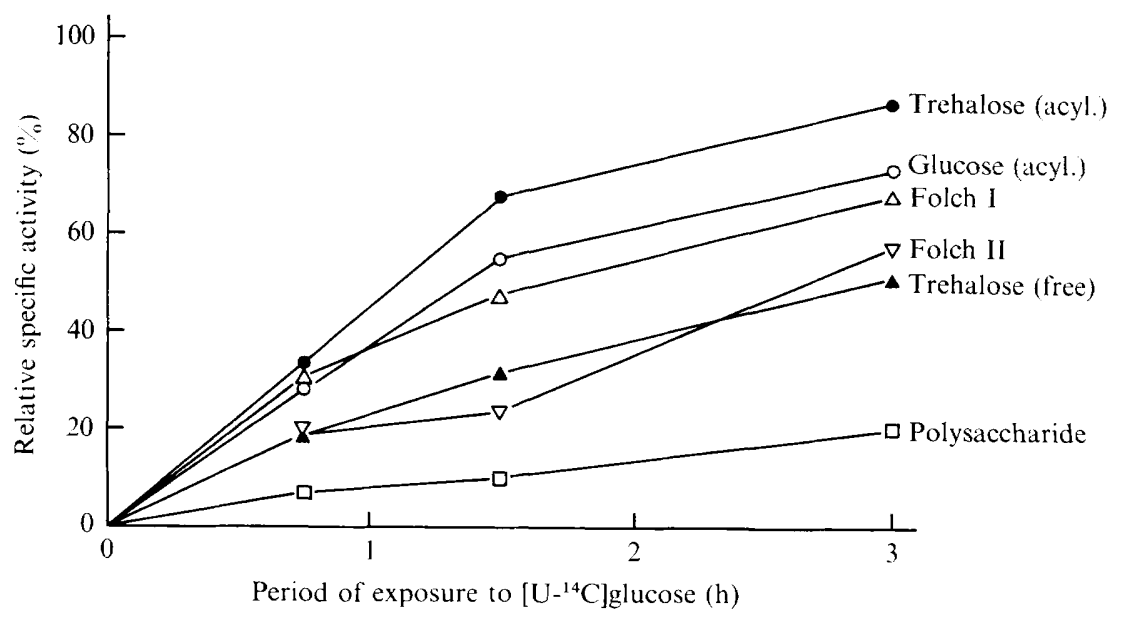

Fig. I. Kinetics of incorporation of $\left[\mathrm{U}^{14} \mathrm{C}\right]$ glucose into fractions from growing cultures of Mycobacterium smegmatis. Specific activities were calculated as d.p.m./mg and these values are expressed as a percentage of the corresponding value for the glucose in the medium. from acyltrehalose; $O$, glucose from acylglucose; $\boldsymbol{\Delta}$, free trehalose; $\Delta$, Folch I fraction; $\nabla$, Folch II fraction; $\square$, glucose from polysaccharide.

fraction was trehalose, this 'specific activity' provided an independent measure of the upper limit of the specific activity of trehalose. As expected, this 'specific activity' proved to be consistently above, though not far above, that of the trehalose from the fraction (Fig. I).

The total free lipid (Folch II fraction) was also labelled at an intermediate rate (Fig. I). When glucose and trehalose were isolated from their acylated forms by the saponification of this lipid followed by chromatography, they were found to be labelled rapidly, particularly trehalose (Fig. I).

There was no lag in the labelling of any component and, hence, any pools between these components and the glucose in the medium were small. The soluble pool of carbohydrate phosphates, and carbohydrates with the exception of trehalose, is indeed known to be small in mycobacteria (Winder, Brennan \& McDonnell, 1967; Winder \& Rooney, 1970).

\section{Calculation of turnover of sugars}

The results of the experiments described above suggested marked turnover in the sugars derived from the lipid fraction and, to a less extent, in the free trehalose. Calculation of the amount of turnover involved was made as follows.

In growing cells, a 'turnover number' can be defined for any compound as the number of units of the compound turned over per unit amount of net formation. This number is thus defined by the equation

$$
N=\frac{\alpha-\beta}{\beta}=\frac{\alpha}{\beta}-\mathrm{I},
$$

where $N$ is the turnover number, $\alpha$ is the rate constant for the synthesis of the compound, and $\beta$ is the rate constant for the net formation of the compound. Under conditions of balanced growth, the rate constant for the net formation of the compound is equal to the rate constant for net accumulation of bacterial mass, so that equation (I) can be replaced by

$$
N=\frac{\alpha}{\gamma}-\text { I, }
$$


Table I. Concentration of glucose in medium and of sugars in bacteria during incorporation of $\left[{ }^{14} \mathrm{C}\right]$ glucose into Mycobacterium smegmatis

\begin{tabular}{|c|c|c|c|c|}
\hline \multirow{2}{*}{$\begin{array}{l}\text { Period of } \\
\text { incorporation } \\
\text { (h) }\end{array}$} & \multirow{2}{*}{$\begin{array}{c}\text { Glucose } \\
\text { concentration } \\
\text { in medium } \\
(\mathrm{mg} / \mathrm{ml})\end{array}$} & \multicolumn{3}{|c|}{ Amount of sugar in bacteria ( $\mu \mathrm{g} / \mathrm{mg}$ bacterial residue) } \\
\hline & & Free trehalose & Acylated trehalose & Acylated glucose \\
\hline $\mathrm{I} \cdot 5$ & $8 \cdot 7$ & 35 & $3 \cdot 0$ & 2.0 \\
\hline 3.0 & $8 \cdot 5$ & 29 & $4 \cdot 6$ & $2 \cdot I$ \\
\hline 6.0 & $7 \cdot \mathrm{I}$ & 34 & $2 \cdot 7$ & $\mathrm{I} \cdot 7$ \\
\hline 8.0 & 6.8 & 34 & $3 \cdot I$ & $\mathrm{I} \cdot 4$ \\
\hline
\end{tabular}

where $\gamma$ is equal to the rate constant for net accumulation of bacterial mass, or the growth constant of the bacteria.

Further, for cells in balanced exponential growth and for compounds containing approximately the same percentage carbon as glucose, the following equation can be derived from equation (2):

$$
N=\frac{t_{d}}{T_{50 \%} \text { sp.act. }}-\mathrm{I},
$$

where $T_{50 \% \text { sp.act. }}$ is the time required for the specific activity of the compound to reach $50 \%$ of that of the glucose in the medium, and $t_{d}$ is the doubling time for total bacterial mass.

The rate constants for the synthesis of compounds can, in principle, be determined from the initial rates of incorporation of radioactivity. However, in practice, with a limited number of sampling times, initial rates of incorporation are difficult to determine reliably for compounds with various rates of synthesis. In the cases of compounds in which we were particularly interested, more reliable estimates could be made of the time required for the compounds to reach $50 \%$ of the specific activity of the glucose in the medium. In addition, these $50 \%$ labelling times should be less susceptible to the effects of any precursor pools which may exist than would the initial rates of synthesis.

In the derivation of equation (3), exponential growth and balanced growth were assumed. In fact, due to the granular form of growth of Mycobacterium smegmatis in the absence of Tween 80 even in shaken culture, growth of the bacteria was not exponential (see also Winder \& Rooney, 1970; Winder \& Coughlan, 1971). However, this does not appreciably affect employment of the $T_{50 \% \text { sp.act. }}$ in the case of the compounds of interest as, in these cases, this time was short compared with doubling time of the bacteria. The doubling time of the bacteria over the experimental period was approximated by determining it over a I $2 \mathrm{~h}$ period extending equally before and after the experimental period.

Although, in view of the decelerating growth rate, bacteria were unlikely to be in a precisely balanced state of growth, changes in composition of the bacteria in a fraction of the doubling time were likely to be comparatively small and, indeed, in our experience changes in composition of mycobacteria during decelerating growth are relatively slow (Winder \& Rooney, 1970; Winder \& Coughlan, 1971). The data in Table I show that the free trehalose content of the bacteria was constant over the experimental periods involved. Assays of the acylated trehalose and particularly the acylated glucose were less reliable, due to their low concentrations in the bacteria and the fact that the methods employed were designed for accurate measurement of the specific activities of these compounds rather than their amounts in the bacteria. However, the results for them in Table I show no clear evidence of variation of their content in the bacteria and certainly no evidence of an amount of variation which would upset the conclusions below. 


\section{Table 2. Turnover of carbohydrates in Mycobacteria smegmatis during growth on glucose as sole carbon source}

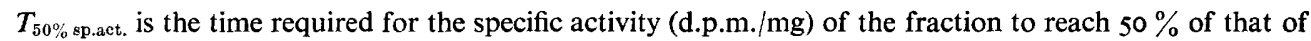
the glucose in the medium. Values for three experiments are given, with the mean in parentheses.

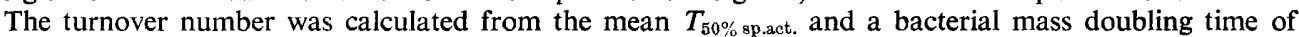
$12 \mathrm{~h}$ by the use of equation (3) in the text.

\begin{tabular}{|c|c|c|c|c|}
\hline Fraction & $\begin{array}{l}T_{50_{\%}^{\circ} \text { sp.act. }} \\
\text { (h) }\end{array}$ & $\begin{array}{l}\text { Turnover } \\
\text { number }\end{array}$ & $\begin{array}{l}\text { Percentage of } \\
\text { bacterial dry wt }\end{array}$ & $\begin{array}{l}\text { Percentage of bacterial wt } \\
\text { which could pass through } \\
\text { fraction }\end{array}$ \\
\hline Free trehalose & $\begin{array}{c}2 \cdot 20,2 \cdot 93,3 \cdot 13 \\
(2 \cdot 75)\end{array}$ & $3 \cdot 4$ & $3 \cdot 0$ & $10 \cdot 2$ \\
\hline Free lipid & $\begin{array}{c}4 \cdot 00,2 \cdot 54,6 \cdot 50 \\
(4 \cdot 35)\end{array}$ & $1 \cdot 8$ & $12 \cdot 0$ & 22 \\
\hline Acylated trehalose & $\begin{array}{c}0.70,0.98,0.93 \\
(0.87)\end{array}$ & $12 \cdot 8$ & 0.3 & $3 \cdot 8$ \\
\hline Acylated glucose & $\begin{array}{c}I \cdot I 3, I \cdot 40, I \cdot 43 \\
(I .32)\end{array}$ & $8 \cdot I$ & 0.2 & $I \cdot 6$ \\
\hline
\end{tabular}

As a result of the above considerations, to make approximate comparisons of the relative rates of turnover of the compounds under investigation, the time required for each component to reach $50 \%$ of the specific activity of the glucose in the medium was determined from three experiments of the type illustrated in Fig. I, in which the bacteria had the same doubling time. From the mean values so obtained turnover numbers were calculated as explained above and are given in Table 2.

The results in Table 2 confirm that the glucose and trehalose of acylated glucose and trehalose turned over very rapidly, about Io times per cell generation. By contrast, the results for the bulk of free lipid suggest that this fraction turned over relatively slowly. Since this lipid presumably had a higher carbon content than glucose, which would lead to overestimation of the turnover number, turnover of this fraction was probably less than the figures indicate. Thus, the turnover of the acyl portions of the acylated sugars was not simply a reflection of general lipid turnover.

Free trehalose showed appreciable turnover, though much less than its acylated form.

The bacterial residue and the glucose in the insoluble polysaccharide were labelled so

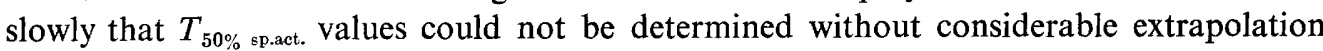
beyond the experimental points. Hence the increase in specific activity per h over an early experimental period (e.g. between 0.75 and $3 \mathrm{~h}$ in the experiment illustrated in Fig. I) was calculated as an approximation to the rate constant for the synthesis of these two fractions. In the case of the cell residue the rate constant so obtained was little different from the growth rate constant for bacterial mass, obtained from the doubling time, indicating that little turnover of the bacterial residue was taking place, while the rate constant in the case of the glucose from the polysaccharide in the cell residue was not much greater and indicated a turnover number of less than 0.5 .

The significance, in the context of the bacterial economy, of the turnover of free trehalose and of its acylated form and that of glucose, can be appreciated from Table 2 which gives the percentage of bacterial dry wt which these sugars provide. By multiplying these figures by the turnover number an approximate indication is obtained for the proportion of the total bacterial wt which could pass through these sugars by virtue of their turnover. The results show that this is small, so that they do not represent major metabolic intermediates. 


\section{DISCUSSION}

The results described above give some information about the metabolism of acylated glucose and trehalose and place some restrictions on hypotheses about their biological roles.

With the acylated forms of these sugars turning over about ten times per bacterial generation, their primary role is probably not a storage one. If their role were storage, better regulation of their breakdown would be expected in these experiments in which the concentration of glucose remained high throughout. Likewise, their role is not solely structural: if they have a structural role it involves metabolic turnover as well.

On the other hand, the extent of their turnover in the context of the relatively small amounts present in the bacteria indicates that their metabolic role is not quantitatively a major one in the bacterial economy. For example, the hypothesis is not tenable that these acylated sugars represent a major transport form of glucose through the bacterial membrane, as has been suggested for other glucose-containing lipids (Smith, I969).

These acylated sugars could be incorporated as such into acylated polysaccharides. The turnover of their fatty acids, which would provide evidence on this possibility, has not been carefully examined. However, such data as were obtained on this suggests that the turnover of these fatty acids is less than that of the sugars (unpublished observations).

The turnover of the acylated sugars is not due to loss to the medium: only minute amounts could be found in the medium (unpublished observations), as may be expected from their low water solubility.

Hence, the metabolic role of these acylated sugars, and with it an explanation of their high degree of turnover, remains unexplained.

In mycobacteria, acylated sugars and triglycerides are replaceable by each other to at least some degree depending on the composition of the medium. When mycobacteria are grown in a medium which contains glycerol in place of glucose, acylated sugars are present in smaller amounts and there are increased amounts of triglycerides which rapidly turnover (Brennan et al. 1970; Brennan, Rooney \& Winder, 1970).

The route of biosynthesis of acylated trehalose is also unexplained. The most obvious precursor, free trehalose, is labelled too slowly to be a precursor of the acylated form, unless there is more than one pool of free trehalose. This does not seem impossible: for example, trehalose may be synthesized in the cell wall or membrane and a small proportion of it may be immediately acylated there, while the remainder is transferred to a relatively inert pool in the cell interior. Alternatively, acyltrehalose may be synthesized directly from trehalose phosphate which is the precursor of free trehalose (Cabib \& Leloir, I958; Matula, Mitchell \& Elbein, 1971).

Elucidation of the metabolism, and perhaps the role, of these acylated sugars will probably come from studies in vitro on enzyme systems which can acylate these sugars and carry out their subsequent metabolism.

We thank Professor T. D. Spearman, Department of Applied Mathematics, for advice on mathematical problems, and Miss Angela Laverty for technical assistance. This research was supported by a grant from the National Science Council, Republic of Ireland. 


\section{REFERENCES}

ANET, E. L. F. J. \& ReYNolds, T. M. (I954). Isolation of mucic acids from fruits. Nature, London $\mathbf{1 7 4 , 9 3 0 .}$

Ballou, C. E., Vilkas, E. \& Lederer, E. (I963). Structural studies on the myoinositol phospholipids of Mycobacterium tuberculosis (var. bovis strain BCG). Journal of Biological Chemistry 238, 69-76.

BraY, G. A. (I960). A simple efficient liquid scintillator for counting aqueous solutions in a liquid scintillation counter. Analytical Biochemistry I, 279-285.

Brennan, P. J., Flynn, M. P. \& Griffin, P. F. S. (1970). Acylglucoses in Escherichia coli, Saccharomyces cerevisiae and Agaricus bisporus, FEBS Letters 8, 322-324.

Brennan, P. J. \& Lehane, D. P. (1969). Acylglucoses in corynebacteria. Biochimica et biophysica acta 176, $675-677$.

Brennan, P. J., Lehane, D. P. and Thomas, D. W. (I970). Acylglucoses of the corynebacteria and mycobacteria. European Journal of Biochemistry 13, I I 7-1 23.

Brennan, P. J., Rooney, S. A. \& Winder, F. G. (1970). The lipids of Mycobacterium tuberculosis BCG: fractionation, composition, turnover and the effects of isoniazid. Irish Journal of Medical Sciences 3, 37 I -390 .

CABib, E. \& Lelorr, L. F. (1958). The biosynthesis of trehalose phosphate. Journal of Biological Chemistry 231, 259-275.

Dubois, M., Gilles, K., Hamilton, J. K., Rebers, P. A. \& Smith, P. F. (1956). Colorimetric method for determination of sugars and related substances. Analytical Chemistry 28, 350-356.

Folch, J., Lees, M. \& Sloane-Stanley, G. H. (1957). A simple method for the isolation and purification of total lipids from animal tissues. Journal of Biological Chemistry 226, 497-509.

Matula, M., Mitchell, M. \& Elbein, A. D. (I971). Partial purification of a highly specific trehalose phosphate phosphatase from Mycobacterium smegmatis. Journal of Bacteriology 107, 21 7-222.

Noll, H., Bloch, H., Asselineau, J. \& Lederer, E. (I956). The chemical structure of the cord factor of Mycobacterium tuberculosis. Biochimica et biophysica acta 20, 299-309.

SHAw, N. (1970). Bacterial glycolipids. Bacteriological Reviews 34, 365-377.

Sмiтh, P. F. (1969). The role of lipids in membrane transport in Mycoplasma laidlawii. Lipids 4, 331-336.

SMITH, P. F. \& MAYBERRY, W. R. (I968). Identification of the major glycolipids from Mycoplasma sp., Strain J. as 3,4,6-triacyl- $\beta$-D-glucopyranose. Biochemistry 7, 2706-2710.

Welsh, K., Shaw, N. \& Baddiley, J. (1968). The occurrence of acylated sugar derivations in the lipids of bacteria. Biochemical Journal 107, 313-314.

Winder, F. G., Brennan, P. J. \& MCDonnell, I. (1967). Effects of isoniazid on the composition of mycobacteria, with particular reference to soluble carbohydrates and related substances. Biochemical Journal I04, 385-393.

Winder, F. G. \& Coughlan, M. P. (I97I). Comparison of the effects of carbon, nitrogen and iron limitation on the growth and on the RNA and DNA content of Mycobacterium smegmatis. Irish Journal of Medical Science 140, 16-25.

WINDER, F. G. \& Rooney, S. A. (1970). Effects of nitrogenous components of the medium on the carbohydrate and nucleic acid content of Mycobacterium tuberculosis BCG. Journal of General Microbiology 63, 29-39. 